\title{
Editorial
}

\section{Taking stance against the challenges of communicable diseases and antimicrobial resistance}

Hans-Joachim Freisleben

This issue presents some very important topics which can be grouped into research on physical exercise and communicable diseases, tuberculosis, fungal eye infection, and methicillin-resistant Staphylococcus aureus (MRSA). Although the other contributions in this issue are not less interesting, they will not be discussed in this editorial.

The two articles "The effects of intensity and duration of aerobic exercise on spatial memory function in male Wistar rats" and "Combination of aerobic exercise and environmental enrichment improves spatial memory and enhances neuroligin 1 expression" belong to a series of publications on the effects of physical exercise on cerebral functions, in this case spatial memory using the water E-maze model, recently depicted and described. ${ }^{1}$ These articles demonstrate that low intensity and long duration have better effects than short duration and high intensity and that positive environmental influence ("environmental enrichment" in the animal experiments) further improves spatial memory as tested in the experiments. During the last decade, aerobic and anaerobic exercise in animal training programmes with varying intensities and duration effects on myocardium and brain yielded results, which can be very helpful to human physical exercise and sports medicine. Both positive and negative effects have been shown on neural plasticity, especially synaptic plasticity and the expression of neurotransmitters and hormones, from mild or moderate training up to an overtraining model impairing neural functions known as overtraining syndrome. In Indonesia, this has become a wide field of research which will hopefully end up not only in improved training methods for athletes, but also in suitable sports activities for the rehabilitation of patients.
Another very important aspect can be seen from ongoing research projects. When the writer of this editorial started to work at Indonesian universities in the beginning of the nineties of last century, no such research projects existed. Then, we made efforts to establish continuous biomedical research, which was difficult in the beginning, because it took some years, until we could offer such ongoing projects and students came still up with their own research ideas, some of which were worth to be investigated -more or less- with supervisors who were not always experts in the field of the student's research interest. By the end of the last millennium, we could already offer a spectrum of biomedical research projects that could be joined by Master and Doctoral students. So, the "individual" research interests of students were step by step replaced by ongoing research projects offered by the Study Program Biomedicine and some Departments. Soon, a working group in the field of experimental physical exercise was established at the Department of Physiology, Faculty of Medicine, Universitas Indonesia. Meanwhile, such working groups on experimental physical exercise exist also at other Indonesian universities and together, they have already produced a remarkable number of publications.

The second field in this issue concerns communicable diseases and antimicrobial resistance (AMR) with a report on MRSA prevalence in Pakistan and two articles on tuberculosis (TB). According to World Health Organization (WHO), more than 3\% of new TB are multidrug-resistant, even up to $20 \%$ among people with previous anti-TB treatment and almost $10 \%$ of them exert extensively drug-resistant tuberculosis (XDR-TB) with resistance towards at least four anti-TB drugs. ${ }^{2}$ Food and Drug Administration just approved pretomanid (by non-profit TB Alliance) for XDR-TB

Copyright @ 2019 Author. This is an open access article distributed under the terms of the Creative Commons Attribution-NonCommercial 4.0 International License (http:// creativecommons.org/licenses/by-nc/4.0/), which permits unrestricted non-commercial use, distribution, and reproduction in any medium, provided the original author and source are properly cited. 
treatment, in combination with bedaquiline and linezolid. Nevertheless, sufficiently sensitive, selective and rapid diagnosis as well as safe and effective vaccination are still essential. Two papers elucidate these topics: "A recent update of the diagnostic methods for tuberculosis and their applicability in Indonesia" reviews diagnostic tests available during recent years, as for instance, GeneXpert which is recommended by WHO. The second article in this field "Glutathione S-transferase-resuscitationpromoting factor B recombinant protein of Mycobacterium tuberculosis induces the production of interferon- $\gamma$ and interleukin-12 in mice splenocytes" provides information on a possibly novel vaccination towards TB.

Last, but not least, there is an excellent paper on Aspergillus flavus endophthalmitis in an experimental rabbit model. The article compares intravitreal injection of voriconazole (VCZ) and amphotericin $B(A m B)$. From their results, the authors conclude that intravitreal injection of $100 \mu \mathrm{g}$ voriconazole (VCZ) has a tendency to better clinical improvement and anatomical structure preservation than 5 $\mu \mathrm{g} A m B$ solubilized with deoxycholate (AMB-D) and administered via the same route. Concerning tolerability, the authors refer to other studies: "The safety of intravitreal injection of $100 \mu \mathrm{g}$ VCZ and 5 $\mu \mathrm{g} A \mathrm{mB}$ has previously been reported in numerous studies."3 As for AmB, most studies compare different pharmaceutical preparations, so does the cited publication: AMB-D, AmB lipid complex $(A B L C)$, and liposomal $A m B(L-A m B) .{ }^{4}$ In addition to the above citation, another sentence may be cited from the same reference: "However, based on ophthalmologic data, L-AmB appears to be less toxic than either amphotericin B deoxycholate or ABLC."4 Hence, it might be advisable to use L-AmB for intravitreal injection instead of $A m B$ deoxycholate. L-AmB was also recommended for the treatment of endogenous candida endophthalmitis in humans. ${ }^{5}$ In Indonesia, a study with topical L-AmB eye drops has been conducted in a rabbit keratomycosis model with four different Aspergillus species including $A$. flavus. ${ }^{6}$

From Medical Journal of Indonesia; German-Indonesian Medical Association (DIGM)

pISSN: 0853-1773 • elSSN: 2252-8083

https://doi.org/10.13181/mji.v28i3.4219

Med J Indones. 2019;28:205-6

Corresponding author:

Hans-Joachim Freisleben

E-mail: hj.freisleben@t-online.de

\section{REFERENCES}

1. Ilyas El, Irawati D, Elfiza D, Nurlaela C, Jusman SW, Kartinah NT. The potency of Hibiscus sabdariffa Linn. on decreased memory function related to the level of BDNF and CREB in hippocampus of overtrained rats. Int J Recent Sci Res. 2017;8(5):17097-103.

2. World Health Organization [Internet]. Antimicrobial resistance. 2018 [cited 2019 Sept 2]. Available from: https://www.who.int/ news-room/fact-sheets/detail/antimicrobial-resistance

3. Arianti A, Setiabudy R, Rozaliyani A, Siregar NC, Susiyanti M. Comparison of intravitreal antifungal $100 \mu \mathrm{g}$ voriconazole and $5 \mu \mathrm{g}$ amphotericin $\mathrm{B}$ in experimental Aspergillus flavus endophthalmitis model in rabbits. Med J Indones. 2019;28(3):215-22.

4. Cannon JP, Fiscella R, Pattharachayakul S, Garey KW, De Alba $\mathrm{F}$, Piscitelli $\mathrm{S}$, et al. Comparative toxicity and concentrations of intravitreal amphotericin B formulations in a rabbit model. Invest Ophthalmol Vis Sci. 2003;44(5):2112-7.

5. Bae JH, Lee SC. Intravitreal liposomal amphotericin B for treatment of endogenous candida endophthalmitis. Jpn J Ophthalmol. 2015;59(5):346-52.

6. Husnun A. Profil farmakokinetik dan uji efektifitas tetes mata amfoterisin B liposom pada keratomikosis kelinci [dissertation]. Jakarta (Indonesia): Universitas Indonesia; 2015. Indonesian. 